\title{
Integration of Shari'ah Governance Framework in Human Resource Management Practice in Malaysia
}

\author{
Atirah Binti Sahidon, Rusni Hassan, Shamsuddin Abdullah, Syed Ahmed Salman
}

\begin{abstract}
The discussion on Shari ah governance has gained significant attention and concerns in the Islamic finance industry. The Central Bank of Malaysia (BNM) introduced the Shariah Governance Framework for Islamic Financial Institutions (SGF) in 2010 for the purpose of promoting effective and good Shariah governance practices of Islamic Financial Institutions. The IFIs are expected to integrate necessary elements of good Shari'ah governance structure and processes in order to sustain their business in this complex environment as well as to ensure effective implementation of SGF through effective Human Resources Management (HRM). Many studies have been done on the Shariah governance aspects, processes and its effectiveness but not on the impact of HRM in SGF implementation. Therefore, the present study examines the SGF from HRM perspective particularly on the integration between SGF and HRM. It approached the topic from the perspective of job design and description through a literature review and a survey of professionals from the Shariah Division and $\mathrm{HR}$ Division of different types of IFIs in Malaysia. The data were collected from the literature review and survey responses from 78 respondents from different IFIs. The study found seven HRM scopes highlighted in the framework and found that the respondents' general understanding of SGF implementation and HRM practices was satisfactory. Remarkably, it is also found that theIFIs have effectively used their HRM practices from the job design and description perspective as a tool to manage their key Shariah governance organs. Several limitations and recommendations were also presented to further enhance SGF implementation from this perspective.
\end{abstract}

Index Terms: Human Resource Management, Shari'ah Governance, Islamic Financial Institutions, Malaysia

\section{INTRODUCTION}

Shari'ah principles and rulings are an essential aspect in the development of Islamic finance and regarded as the backbone of the Islamic finance industry. Its fundamental objective or known as "Maqasid Shari'ah" is primarily to attain and ensure the well-being and welfare of all mankind, in worldly life and the Hereafter. Shari'ah principles are "syumul" and comprehensive in which it is encompassing and covering all

Revised Manuscript Received on November 11, 2019.

Atirah Binti Sahidon, Master's Candidate at IIUM Institute of Islamic Banking and Finance (IIBBF), International Islamic University Malaysia (IIUM). Email: atirahsahidon@gmail.com

Rusni Hassan, Professor at IIUM Institute of Islamic Banking and Finance (IIiBF), International Islamic University Malaysia (IIUM). Email: hrusni@iium.edu.my

Shamsuddin Abdullah, Lecturer, Centre of Foundation Studies, International Islamic University Malaysia (IIUM). Email: shamsuddin@iium.edu.my

Syed Ahmed Salman, Senior Lecturer at Faculty of Business and Accountancy, Lincoln University College, Malaysia. Email: salmaniium@gmail.com aspects of life such as ibadah, aqidah and muamalat (ISRA, 2012). As for Islamic Finance, Shari'ah has underlined strict rules and requirements as well as principles to be adhered to in any financial dealings and transactions or known as "Fiqh Muamalat" which is mainly to promote better interaction and relationship between human beings. Presently, there are significant efforts and cooperation between Islamic finance players to complement the need for Shari'ah-compliant products and transactions offerings in the industry while fulfilling the Shari'ah objectives as guided by Islam. This growing industry has gained significant attention and involvement not only from Muslim countries but also from non-Muslim countries.

As the industry grows, there is a crucial need for comprehensive and proper regulation and legal framework to ensure that all Islamic finance activities and operations including Islamic banking, takaful, Islamic investment, and other areas are in line with Shari'ah principles. The essential aspect that needs to be tightened is the enforcement of comprehensive and effective Shari'ah governance. Shari'ah governance is the fundamental element embedded into Islamic finance industry to promote integrity, transparency, accountability, and responsibilities among its stakeholders while protecting the rights and interest of its shareholders and stakeholders (ISRA, 2012). The purpose of this regulatory and supervisory framework is to ensure the overall compliance of Islamic financial institutions (hereinafter referred as "IFI") in business and at all levels of operations. An adequate and efficient Shari'ah governance framework needs to be properly put in place to prevent undermining the integrity of the Islamic financial system as a whole.

A proper Shari'ah governance practice will provide the assurance needed by shareholders and the public to commit themselves to Islamic finance which clearly demonstrates the importance of the Shari'ah governance framework to the industry. The SGF features are distinctive as it is not only confined to aspects of Shari'ah compliance as mentioned above but possess corporate governance elements and components embedded in it. This is among the distinguishing features or differences which are present in the Islamic financial system compared to the conventional system which relies on the corporate governance system only (Hasan, 2009). This unique institutional structure only applies to the IFIs. Hence, Shari'ah governance is another component that is exclusive to Islamic finance practitioners.

It has been observed that Shari'ah governance practice and implementation in the Islamic finance industry varies from one jurisdiction to another. In general, the framework

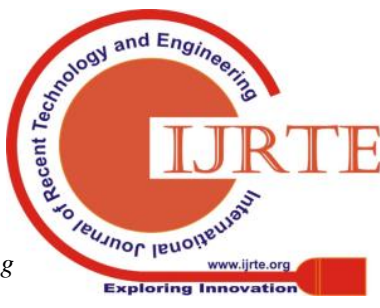


consists of two Shari'ah supervisory levels, at the regulator's level and financial institutions' level (BNM, SGF, 2010). Some jurisdictions adopt the former and some the latter while other jurisdictions adopt both supervisory levels. These jurisdiction variations have led to different roles and responsibilities played by the Shari'ah Advisory Council at the regulators' level and Shari'ah Advisors at the financial institutions' level.

In the Malaysian context, all IFIs licensed by Bank Negara Malaysia (hereinafter referred to as "BNM") are mandated to operate in accordance with Shari ah principles. In 2010, BNM first introduced its Shari'ah Governance Framework for Islamic Financial Institutions (herein after referred to as "SGF") to provide an assurance of Shari ah compliance in the IFIs operations and business activities. Generally, it is to ensure these operators continuously operate as per SGF requirements. The primary objective of the SGF issuance is to enhance the role of the Board, the Shari ah Committee and the Management in relation to Shari ah matters as well as to enhance the relevant key organs by executing its responsibilities and roles to ensure the bank's operations are compliant with the Shari ah. The SGF is also expected to encourage the industry to enhance their internal controls and processes either to address or to mitigate any Shari'ah non-compliance risks and occurrence as guided.

The implementation of SGF in the Malaysian IFIs since 2010 has generally enhanced the Shariah compliance aspects of the IFIs operations. It was reported that Malaysia's SGF is currently being emulated by Bahrain, Pakistan, and the United Arab Emirates as it is regarded as the most structured and advanced Shari'ah governance framework in the world. The issuance of SGF in 2010 is further complemented with the Islamic Financial Services Act 2013 and the Development Financial Institutions Act 2002 (Parker, 2017).

The whole structure and implementation of SGF are reflected in the effective and efficient key organs at the institutions; at the top and middle management levels as well as at the operations level of an IFI. In the absence of effective arrangements and functions of relevant key organs of the SGF, the expected implementation of the framework may not succeed. In other words, the responsibility of having it implemented successfully lies heavily in the function of the Human Resource Management (hereinafter referred as HRM) of an IFI since it also involves people who are the management and the employees of the IFIs. For comprehensive SGF implementation, the duties and responsibilities of the key governance organs must be satisfactorily performed. A clear understanding of their roles and duties ensures a successful and effective implementation of the framework. Hence, a clear job design and a description of key governance organs are essential to promote good governance practices in an IFI in a holistic manner.

This study focuses on the function of HRM particularly on the two key aspects of job design and description of Shari'ah governance key organs of an IFI. Fundamentally, it also covers topics related to the general understanding of SGF implementation as well as the incorporation of the HRM requirements in Shariah governance practices of the IFIs.

\section{LITERATURE REVIEW}

As a reference to the discussion, it is also relevant to include HRM aspects as a basis to support and strengthen the discussion on Shari'ah governance.

A study conducted by Huselid, Jackson and Schuler (1997) investigated the impact of HR managers' capabilities on HRM management effectiveness and the latter's impact on corporate financial performance. It was done on senior executives of HRM from 239 public U.S firms. The result showed that HRM effectiveness was associated with HR staffs' capabilities and attributes. It also suggested that there was a relationship between productivity, cash flow, market value and HRM management effectiveness. From this study, effectiveness of HRM is always associated with its human capital management as its key driver to enhance the performance of an organization. The same applies for implementation of SGF in Malaysian context. However, the scope of this study was not conducted in the Malaysian context and it was not done on SGF.

In 2014, McKinsey performed a survey involving 770 directors from public and private companies in different industries globally. This study investigated the relationship between directors' time allocation and effectiveness of the Board (Bhagat and Kehoe, 2014). The results indicated that highly committed boards (i.e., spent more time) were seen as having better and effective management. The time spent was invested in organizational strategy, performance management, execution and investment, organizational health and talent development, business-risk management and lastly, core governance and compliance as their agenda. It should be noted that governance and compliance matters were among the main priorities put by these engaged directors. Nevertheless, it did not deny the fact that human capital is still crucial as they assume the key role to ensure this governance and compliance issues are managed accordingly.

Knightsbridge et al. (2011) investigated the role and effectiveness of human capital oversight among 242 Canadian boards of directors. The findings revealed that the boards have direct responsibilities for matters in relation to Chief Executive Officer's compensation, development, performance management and succession planning. The boards also recognized the importance of human talent and believed that they also have responsibility on HRM matters such as HR strategy, employee engagement, and organizational culture, succession planning as well as development and learning. The recognition of boards towards human capital management showed that it is an important element to ensure their organization achieve its strategic objectives. The scope of this study was investigated in the Canadian context and not from the Malaysian context. Also, the study was not conducted on IFIs and SGF.

Since human capital capabilities and management is part of Board's agenda and as one of the key organs to implement SGF within its IFI, the responsibility of ensuring both practices are simultaneously integrated inarguably lies in the hand of the management and relevant key organs. These key governance organs are managed by HRM division 
who delivers its services in the form of HRM practice. Key governance organs or human capital are the key drivers in this implementation.

Human capital is also a risk for an organization. This risk is always associated with any organization that has employees or potential employees who perform responsibilities and make decisions (Ernst and Young, 2014). Based on a study conducted by Ernst and Young (2014), they ranked several risks associated with human capital risks and the findings also revealed that compliance and regulatory issues are significantly associated with human capital risks. Even though human capital is a risk, when human capital is managed effectively, it promotes and inculcates good HRM practices and thus leads to better implementation of compliance and in this case, SGF implementation. People are motivated by values and not just rules, and this is where HRM plays its role within an organization.

As Islamic finance grows, human capital is one of the key drivers contributing to the success of an IFI. The role of HRM cannot be denied as it copes with different people issues in both executive level as well as management level. Similarly, for Malaysia, the role of HRM is part of SGF implementation process whereby necessary arrangement is designed for the IFI to incorporate the framework into its HRM practices. Relevant principles have been established to integrate different human capabilities and talents with identified roles for the same objectives, known as key governance organs or function.

The link between effective SGF and HRM practice can be referred to the work of Shafii et al. (2013) who conducted a study to identify the independence and competency qualities that are required for human capital development in Shari'ah Audit. This study used focus group interviews whereby five respondents from Shari'ah Audit participated in the interview. The findings indicated that Shari'ah auditors must possess Shari'ah and accounting knowledge in order for them to be competent Shari'ah auditors. To ensure the independence of the Shari'ah auditors, they should be attached to the internal audit department. This study emphasized the need for a competent and independent Shari'ah audit function within an IFI, which is part of HRM practice to ensure this role is effective. However, the scope of the study was not based on the required key governance organs in the SGF but based on the Shari'ah Audit function.

Harun and Abdullah (2017) conducted a study to explore the practical adoption of theories to further enhance the SGF by management teams of IFIs in Malaysia. Thirty-nine respondents were from various departments and job positions in a Takaful operator based in Malaysia. The results showed that the management of Malaysian IFIs including Takaful companies is classified as effective. It was further recommended that effective organization was needed to establish excellence rapport between operations and top management levels which would simultaneously promote robust governance in Islamic finance industry. However, it did not cover all IFIs' operation and other SGF governance key functions (i.e., Board of Directors, Shari'ah Committee and Shari'ah Compliance functions).

Several researchers have found that IFIs have failed to ensure its business and operation were Shari'ah compliant
(Yussof, 2013). One of the main reasons behind this failure is inadequate or ineffective Shari'ah systems and controls particularly in the area of external and internal Shari'ah audit (Rahman, 2008). With reference to this statement, to reiterate, the accountability to ensure effective implementation of SGF lies on the hand of key Shari'ah governance organs. Without having effective management of key Shari'ah governance organs, this implementation may not be a success because SGF is not a Shari'ah issue but involves people issue. Therefore, HRM practices play an integral role in ensuring the effective implementation of SGF in the IFI.

\section{RESEARCH METHODOLOGY}

This field of study which is the effectiveness of SGF implementation and incorporation of SGF by IFIs in Malaysia in its HRM practices in terms of job design and description of the key Shari'ah governance function of an IFI has not been researched extensively by previous studies. Therefore, the researcher employed an exploratory quantitative and qualitative study to investigate the above-mentioned objectives. Sampling method used is non-random sampling. The questionnaire will be analysed mainly by using descriptive statistics. This is the common method of describing the close ended questions (Htay \& Salman, 2013; 2014; Redzuan et al., 2009; Amin \& Rahman, 2011). The researcher made an effort to approach 200 potential respondents. However, only 78 respondents participated in the survey.

\section{FINDINGS}

\subsection{Summary Response for Demographics}

The respondents of survey questionnaires were selected from the networks made available to the researcher. The researcher made an effort to approach 200 potential respondents. However, only 78 respondents participated in the survey. Based on this, the response rate was 39\%. All the 78 respondents worked with the IFIs operating in Malaysia. The description of the respondents was based on gender, age, qualification, job position, specialisation area and department. The respondents' demographicsare outlined in the following tables:

Table 1: Participation Based on Gender

\begin{tabular}{|l|c|c|c|c|}
\hline Gender & Frequency & Percent (\%) & Valid Percent (\%) & Cumulative Percent (\%) \\
\hline Male & 52 & 66.667 & 68.421 & 68.421 \\
\hline Female & 24 & 30.769 & 31.579 & 100.000 \\
\hline Missing & 2 & 2.564 & & \\
\hline Total & 78 & 100.000 & & \\
\hline
\end{tabular}

Majority of the respondents were male employees $(n=52$, $66.67 \%$ ) while female employees constituted $30.77 \%(n=24)$. Two respondents $(2.564 \%)$ from the manual (hard copy) survey distribution did not indicate their gender.

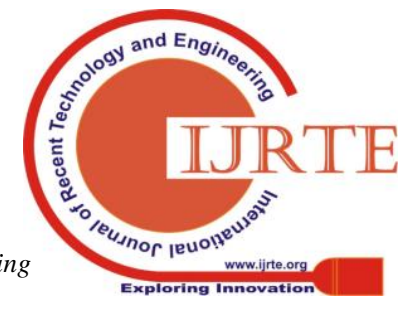


Table 2: Participation based on Job Position

\begin{tabular}{|l|c|c|c|c|}
\hline \multicolumn{1}{|c|}{ Position } & Frequency & Percent (\%) & Valid Percent (\%) & Cumulative Percent (\%) \\
\hline Head of Human Resource & 0 & 0 & 0 & 0 \\
\hline Head of Shar''ah & 8 & 10.256 & 10.256 & 10.256 \\
\hline Officer & 60 & 76.923 & 76.923 & 87.179 \\
\hline Shan'ah Committee & 10 & 12.821 & 12.821 & 100.000 \\
\hline Missing & 0 & 0.000 & & \\
\hline Total & 78 & 100.000 & & \\
\hline
\end{tabular}

Most of the respondents are IFI officers $(n=60,76.92 \%)$. There was no participation from the Head of Human Resource, compared to 8 (10.26\%) Heads of Shari'ah who participated in the survey.

Table 3: Participation based on Specialization Area or Department

\begin{tabular}{|l|c|c|c|c|}
\hline \multicolumn{1}{|c|}{ Department } & Frequency & $\begin{array}{c}\text { Percent } \\
\text { (\%) }\end{array}$ & $\begin{array}{c}\text { Valid } \\
\text { Percent (\%) }\end{array}$ & $\begin{array}{c}\text { Cumulative } \\
\text { Percent (\%) }\end{array}$ \\
\hline Shan'ah Review & 13 & 16.67 & 16.88 & 16.88 \\
\hline Shar'ah Review and Shar'ah Research & 2 & 2.56 & 2.60 & 19.48 \\
\hline $\begin{array}{l}\text { Shar'ah Review, Shar'ahresearch, } \\
\text { Shar''ah Risk Management }\end{array}$ & 1 & 1.28 & 1.30 & 20.78 \\
\hline Shan'ah Research & 27 & 34.61 & 35.06 & 55.84 \\
\hline Shar''ah Risk Management & 4 & 5.13 & 5.19 & 61.03 \\
\hline Shan'ah Audit & 7 & 8.97 & 9.09 & 70.12 \\
\hline Human Resource Management & 6 & 7.69 & 7.79 & 77.91 \\
\hline Shari'ah Committee & 10 & 12.82 & 13.00 & 90.91 \\
\hline Others & 7 & 8.97 & 9.09 & 100.000 \\
\hline Missing & 1 & 1.28 & 1.30 & \\
\hline Total & 78 & 100 & 100 & \\
\hline
\end{tabular}

The highest participating respondents specialised in Shari'ah research area $(n=27,34.61 \%)$ while the lowest number of respondents came from HRM function $(n=6$, 7.69\%). The researcher anticipated higher participation from HRM division or department. However, this was not achieved as expected. There are seven (7) respondents representing other functions or departments within the same IFI under category "others" such as Product Development Department. There were (3) respondents involved in more than one specialisation area at a time.

Table 4: Participation based on Type of IFI

\begin{tabular}{|l|c|c|c|c|}
\hline \multicolumn{1}{|c|}{ Type of IFI } & Frequency & Percent (\%) & Valid Percent (\%) & Cumulative Percent (\%) \\
\hline Islamic Bank & 30 & 38.46 & 44.12 & 44.12 \\
\hline Development Financial Institution & 19 & 24.36 & 27.94 & 72.06 \\
\hline Takaful Operator & 10 & 12.82 & 14.71 & 86.77 \\
\hline Retakaful Operator & 1 & 1.28 & 1.47 & 88.24 \\
\hline Commercial Bank & 8 & 10.26 & 11.76 & 100.00 \\
\hline Missing & 10 & 12.82 & & \\
\hline Total & 78 & 100.00 & & \\
\hline
\end{tabular}

Table 4 shows that respondents from banking institutions substituted $38(48.72 \%)$ respondents. There are $19(24.36 \%)$ respondents representing development financial industry while $11(14.10 \%)$ respondents came from takaful operators. Ten respondents from manual (hardcopy) survey distribution did not indicate their type of IFI.

4.2 Incorporation of Shari'ah Governance Framework in Human Resource Management Practice

Table 5: Distribution for Question 1

\begin{tabular}{|l|c|c|c|c|}
\hline Question 1 & Frequency & Percent (\%) & Valid Percent (\%) & Cumulative Percent (\%) \\
\hline Disagree & 17 & 21.795 & 21.795 & 21.795 \\
\hline Not Sure & 24 & 30.769 & 30.769 & 52.564 \\
\hline Agree & 37 & 47.436 & 47.436 & 100.000 \\
\hline Missing & 0 & 0.000 & & \\
\hline Total & 78 & 100.000 & & \\
\hline
\end{tabular}

Question 1: The Human Resource Division in my institution incorporates Shari'ah Governance matters in its strategies to achieve its target.

The respondents' answers were equally distributed. Almost half of the respondents $(n=37,47.4 \%)$ agreed that the Human
Resource Division (HRD) incorporated Shari'ah Governance matters in its strategies to achieve its target while only 17 $(21.8 \%)$ believed otherwise and $24(30.8 \%)$ were not sure. The results suggested that the HRD was not clear in its implementation of SGF in its strategies as viewed by the respondents.

Table 6: Distribution for Question 2

\begin{tabular}{|l|c|c|c|c|}
\hline Item 2 & Frequency & Percent (\%) & Valid Percent (\%) & Cumulative Percent (\%) \\
\hline Disagree & 17 & 21.795 & 21.795 & 21.795 \\
\hline Not Sure & 24 & 30.769 & 30.769 & 52.564 \\
\hline Agree & 37 & 47.436 & 47.436 & 100.000 \\
\hline Missing & 0 & 0.000 & & \\
\hline Total & 78 & 100.000 & & \\
\hline
\end{tabular}

Question 2: My institution has a clear set of objectives which embeds Shari'ah Governance Framework in Human Resource management practice.

Interestingly, the results were the same as question 1. The results, therefore, indicated that similarly with strategies, the respondents also believed that the HR was not evident in its SGF-embedded objectives.

Table 7 Distribution for Question 3

\begin{tabular}{|l|c|c|c|c|}
\hline Item 3 & Frequency & Percent (\%) & Valid Percent (\%) & Cumulative Percent (\%) \\
\hline Disagree & 11 & 14.103 & 14.103 & 14.103 \\
\hline Not Sure & 11 & 14.103 & 14.103 & 28.205 \\
\hline Agree & 56 & 71.795 & 71.795 & 100.000 \\
\hline Missing & 0 & 0.000 & & \\
\hline Total & 78 & 100.000 & & \\
\hline
\end{tabular}

Question 3: The Human Resource Division of my institution integrates Shari'ah Governance elements in training programs.

Interestingly, in terms of training programs, it was not similar to integration into strategies and objectives. More than half of the respondents $(n=56,71.8 \%)$ agreed that when it comes to training programs, the HRD was clear in its integration of SGF elements.

Table 8: Distribution for Question 4

\begin{tabular}{|l|c|c|c|c|}
\hline \multicolumn{1}{|c|}{ Item 4 } & Frequency & Percent (\%) & Valid Percent (\%) & Cumulative Percent (\%) \\
\hline Disagree & 16 & 20.513 & 20.513 & 20.513 \\
\hline Not Sure & 19 & 24.359 & 24.359 & 44.872 \\
\hline Agree & 43 & 55.128 & 55.128 & 100.000 \\
\hline Missing & 0 & 0.000 & & \\
\hline Total & 78 & 100.000 & & \\
\hline
\end{tabular}

Question 4: The Human Resource Division of my institution seeks inputs and advice from Shari'ah Division on any relevant matters relating to $\mathrm{HR}$ practices and activities.

More than half of the respondents $(n=43,55.1 \%)$ agreed that the HRD sought input and advice from the Shari'ah Division on HR matters. Though marginal, the result suggested that the HRD worked together with the Shari'ah Division in related matters.

Table 9: Distribution for Question 5

\begin{tabular}{|l|c|c|c|c|}
\hline Question 5 & Frequency & Percent (\%) & Valid Percent (\%) & Cumulative Percent (\%) \\
\hline Disagree & 19 & 24.359 & 24.359 & 24.359 \\
\hline Not sure & 34 & 43.590 & 43.590 & 67.949 \\
\hline Agree & 25 & 32.051 & 32.051 & 100.000 \\
\hline Missing & 0 & 0.000 & & \\
\hline Total & 78 & 100.000 & & \\
\hline
\end{tabular}

Published By: 
Question 5: In my institution, the Shari'ah Governance Framework requirements are being incorporated into Human Resource policies, manual and procedures.

Table 9 showed that almost half of the respondents $(n=34$, $43.6 \%$ ) were not sure of the incorporation of SGF in HR policies, manual and procedures. This suggested that it might not be a major concern among the respondents. Table 10 below summarized the result of Section 2 in frequency and percentage output.

Table 10: Summary Results

\begin{tabular}{|c|c|c|c|}
\hline $\mathbf{N}$ & Item & Response / Frequ & / Percentage \\
\hline & The Human Resource Division in my institution incorporates & 1. Agree & $37 / 78(47.4 \%)$ \\
\hline 1 & Shari'ah Govemance matters in its strategies to achieve its & 2. Disagree & $17 / 78(21.8 \%)$ \\
\hline & & 3. Not Sure & $24 / 78(30.8 \%)$ \\
\hline & My institution has a clear set of objectives which embeds & 1. Agree & $37 / 78(47.4 \%)$ \\
\hline 2 & Shari'ah Governance Framework in Human Resource & 2. Disagree & $17 / 78(21.8 \%)$ \\
\hline & management practice. & 3. Not Sure & $24 / 78(30.8 \%)$ \\
\hline & & 1. Agree & $56 / 78(71.8 \%)$ \\
\hline 3 & Shar'ah Governance elements in training programs. & 2. Disagree & $11 / 78(14.1 \%)$ \\
\hline & & 3. Not Sure & $11 / 78(14.1 \%)$ \\
\hline & The Human Resource Division of my institution seeks inputs & 1. Agree & $43 / 78(55.1 \%)$ \\
\hline 4 & and advice from Shar' ah Division on any relevant matters & 2. Disagree & $16 / 78(20.5 \%)$ \\
\hline & & 3. Not Sure & $19 / 78(24.4 \%)$ \\
\hline & In my institution, the Shari'ah Governance Framework & 1. Agree & $25 / 78(32.1 \%)$ \\
\hline 5 & requirements are being incor & 2. Disagree & $19 / 78(24.4 \%)$ \\
\hline & & 3. Not Sure & $34 / 78(43.6 \%)$ \\
\hline
\end{tabular}

Section 4.2 of the survey was provided to study the relationship between SGF and HRM practice by focusing on the incorporation of the framework in general HRM practices by the IFIs. Generally, Item 1 to Item 4 of the section indicated that the understanding of respondents towards this matter was satisfactory by knowing that they were aware and informed of relevant SGF requirements were incorporated in their HRM's practice. Most of the responses showed that the respondents agreed that their HRM's strategies, objectives, training programs as well as general practices incorporated Shari'ah governance elements accordingly. However, Item 5 of the section showed that almost a majority of the respondents were not sure whether their HR's policies, manual and procedures incorporated Shari'ah governance elements in its practice. Potentially, this might be an indicator whether this matter was not a major concern to the respondents or the respondents were not informed by their $\mathrm{HRD}$, or there was no incorporation between these two in their HRM practice.

4.3 Human Resource Management in terms of Job Design and Description of Shari'ah Governance Key Functions

In my institution, responsibilities of the Board of Directors in relation to Shari'ah Governance Framework is clearly set out in writing.

Table 4.11Distribution for Board of Directors

\begin{tabular}{|l|c|c|c|c|}
\hline Question 1 & Frequency & Percent (\%) & Valid Percent (\%) & Cumulative Percent (\%) \\
\hline Disagree & 3 & 3.846 & 3.896 & 3.896 \\
\hline Not sure & 22 & 28.205 & 28.571 & 32.468 \\
\hline Agree & 52 & 66.667 & 67.532 & 100.000 \\
\hline Missing & 1 & 1.282 & & \\
\hline Total & 78 & & & \\
\hline
\end{tabular}

Many of the respondents $(n=52,66.7 \%)$ agreed that the responsibilities of the Board of Directors in relation to Shari'ah Governance Framework was clearly written. A minor $3(3.8 \%)$ group of respondents disagreed with this.
Table 4.12: Written document on responsibilities of Board of Directors in relation to Shari'ah Governance Framework

\begin{tabular}{|l|c|}
\hline \multicolumn{1}{|c|}{ Type of Documents } & Frequency \\
\hline Internal Shari'ah Governance Framework Policy or Manual & 17 \\
\hline Terms of Reference of Board of Directors & 4 \\
\hline Board Charter & 3 \\
\hline Fit \& proper documents for Board of Directors & 1 \\
\hline Internal policies and procedures for Board of Directors & 1 \\
\hline Meeting papers & 1 \\
\hline Shari'ah Compliance Manual or Policy & 1 \\
\hline Terms and conditions of appointment of Board of Directors & 1 \\
\hline Total & 29 of 78 respondents \\
\hline
\end{tabular}

17 out of 29 respondents stated that the responsibilities of the Board of Directors as per SGF requirements were available in the respective IFI's internal Shari'ah governance framework policy $(n=17)$. The remaining respondents claimed that these responsibilities were documented in different types of document such as Terms of Reference, Board Charter and other internal policies and manual as represented by the number stated above.

In my institution, the tasks performed by the Board of Directors have a significant impact on people outside the institution.

Table 4.13 Distribution for Board of Directors

\begin{tabular}{|l|c|c|c|c|}
\hline Item 2 & Frequency & Percent (\%) & Valid Percent (\%) & Cumulative Percent (\%) \\
\hline Disagree & 8 & 10.256 & 10.256 & 10.256 \\
\hline Not sure & 24 & 30.769 & 30.769 & 41.026 \\
\hline Agree & 46 & 58.974 & 58.974 & 100.000 \\
\hline Missing & 0 & 0.000 & & \\
\hline Total & 78 & 100.000 & & \\
\hline
\end{tabular}

More than half of the respondents $(n=46,59.0 \%)$ believed that the tasks performed by the Board of Directors had a significant impact on people outside their institution. While $24(30.8 \%)$ were not sure, only $8(10.3 \%)$ disagreed. Results suggested that respondents had a positive perception towards the impact resulted from the tasks performed by the Board of Directors to people outside the IFI.

Table 4.14Distribution for Board of Directors

\begin{tabular}{|l|l|l|l|l|}
\hline Item 3 & Frequency & Percent (\%) & Valid Percent (\%) & Cumulative Percent (\%) \\
\hline Disagree & 7 & 8.974 & 8.974 & 8.974 \\
\hline Not sure & 12 & 15.385 & 15.385 & 24.359 \\
\hline Agree & 59 & 75.641 & 75.641 & 100.000 \\
\hline Missing & 0 & 0.000 & & \\
\hline Total & 78 & 100.000 & & \\
\hline
\end{tabular}

In my institution, the Board of Directors are provided with significant autonomy in making decision.

More than half of the respondents $(n=59,75.6 \%)$ believed that the Board of Directors were provided with significant autonomy in making a decision. While 12 (15.4\%) were not sure, only $7(9.0 \%)$ disagreed. Results suggested that respondents perceived that the Board of Directors had a significant amount of power given to them. 
Table 4.15Distribution for Management

\begin{tabular}{|l|c|c|c|c|}
\hline Item l & Frequency & Percent (\%) & Valid Percent (\%) & Cumulative Percent (\%) \\
\hline Disagree & 2 & 2.564 & 2.564 & 2.564 \\
\hline Not sure & 18 & 23.077 & 23.077 & 25.641 \\
\hline Agree & 58 & 74.359 & 74.359 & 100.000 \\
\hline Missing & 0 & 0.000 & & \\
\hline Total & 78 & 100.000 & & \\
\hline
\end{tabular}

In my institution, the responsibilities of the Management on Shari'ah Governance matters are clearly set out in writing.

More than half of the respondents $(n=58,74.4 \%)$ believed that the management on Shari'ah governance matters were clearly set out in writing. Only a minor $2(2.6 \%)$ respondents disagreed. Results suggested that the responsibilities of the management were written in such a way that made the respondents took notice.

Table 4.15: Written document on responsibilities of Management in relation to Shari'ah Governance Framework

\begin{tabular}{|l|c|}
\hline \multicolumn{1}{|c|}{ Type of Documents } & Frequency \\
\hline Internal Shari'ah Governance Framework Policy or Manual & 20 \\
\hline Internal policies and procedures for Management & 3 \\
\hline Shari'ah Compliance Manual or Policy & 3 \\
\hline Terms of Reference of Management & 2 \\
\hline Total & 28 of 78 respondents \\
\hline
\end{tabular}

20 respondents stated that the responsibilities of Management team as per SGF requirements were available in their internal Shari'ah governance framework policy or manual. Meanwhile, other documents reported by the respondents were IFIs' internal policies, Shari'ah Compliance policy as well as its Terms of Reference for Management. The result showed that these responsibilities were essentially written and recorded in their internal documents as guidelines to perform responsibilities as required.

Table 4.16Distribution for Management

In my institution, the roles played by the Management involve a great deal of skill variety.

\begin{tabular}{|l|c|c|c|c|}
\hline Item 2 & Frequency & Percent (\%) & Valid Percent (\%) & Cumulative Percent (\%) \\
\hline Disagree & 7 & 8.974 & 8.974 & 8.974 \\
\hline Not sure & 7 & 8.974 & 8.974 & 17.949 \\
\hline Agree & 64 & 82.051 & 82.051 & 100.000 \\
\hline Missing & 0 & 0.000 & & \\
\hline Total & 78 & 100.000 & & \\
\hline
\end{tabular}

Results showed a clear majority of the respondents $(n=64$, $82.1 \%$ ) agreed that the roles played by the management involve a great deal of skill variety. While only seven (7) $(9.0 \%)$ disagreed with this statement.This suggested that the role of the management was believed by the respondents to be challenging.

Table 4.17Distribution for Management

In my institution, the Management is allowed to determine the procedure to be used in carrying out their duties.

\begin{tabular}{|l|c|c|c|c|}
\hline \multicolumn{1}{|c|}{ Item 3 } & Frequency & Percent (\%) & Valid Percent (\%) & Cumulative Percent (\%) \\
\hline Disagree & 1 & 1.282 & 1.282 & 1.282 \\
\hline Not sure & 12 & 15.385 & 15.385 & 16.667 \\
\hline Agree & 65 & 83.333 & 83.333 & 100.000 \\
\hline Missing & 0 & 0.000 & & \\
\hline Total & 78 & 100.000 & & \\
\hline
\end{tabular}

Majority of the respondents $(n=65,83.3 \%)$ agreed that the Management was allowed to determine the procedure to be used in carrying out their duties. Only one (1) respondent
(1.3\%) disagreed with this statement while $12(15.4 \%)$ were not sure. The results suggested that the role of Management was seen as having control over how they operate.

Table 4.22Distribution for Shari'ah Committee The responsibilities of the Shari'ah Committee of my institution are clearly set out in writing.

\begin{tabular}{|l|c|c|c|c|}
\hline Item l & Frequency & Percent (\%) & Valid Percent (\%) & Cumulative Percent (\%) \\
\hline Disagree & 1 & 1.282 & 1.282 & 1.282 \\
\hline Not sure & 6 & 7.692 & 7.692 & 8.974 \\
\hline Agree & 71 & 91.026 & 91.026 & 100.000 \\
\hline Missing & 0 & 0.000 & & \\
\hline Total & 78 & 100.000 & & \\
\hline
\end{tabular}

Majority of the respondents $(n=71,91.0 \%)$ agreed that the responsibilities of the Shari'ah Committee of my institution are clearly set out in writing. Only one (1) respondent (1.3\%) disagreed with this statement while $6(7.7 \%)$ were not sure. The results suggested that responsibilities of the Shari'ah Committee were written in such a way that is clear.

Table 4.18: Written document on responsibilities of Shari'ah Committee in relation to Shari'ah Governance Framework

\begin{tabular}{|l|c|}
\hline \multicolumn{1}{|c|}{ Type of Documents } & Frequency \\
\hline Terms of Reference of Shar' ah Committee & 17 \\
\hline Internal Shar'ah Govemance Framework Policy or Manual & 15 \\
\hline $\begin{array}{l}\text { Internal Shari'ah Govemance Framework Policy and Terms of Reference of Shar''ah } \\
\text { Committee }\end{array}$ & 5 \\
\hline Terms and conditions of appointment of Shar'ah Committee & 3 \\
\hline Internal policies and procedures for Shari'ah Committee & 2 \\
\hline Shari'ah Compliance Manual or Policy & 2 \\
\hline Fit \& proper documents for Shar' ah Committee & 1 \\
\hline Total & 45 of 78 respondents \\
\hline
\end{tabular}

Most respondents claimed that Shari'ah Committee's responsibilities were clearly stated in their Shari'ah Committee's terms of reference $(n=17)$ and internal Shari'ah governance framework policy $(n=15)$. There were five respondents claimed that this requirement was also stated in its both internal Shari'ah governance framework and Shari'ah Committee's terms of reference. The remaining respondents stated that these responsibilities were also written in their internal policies and terms and conditions of the Shari'ah Committee. This showed that the practice of IFIs in documenting Shari'ah Committee's roles and responsibilities were varied.

Table 4.19Distribution for Shari'ah Committee

The tasks performed by the Shari'ah Committee of my institution are very significant in the broader scheme of things.

\begin{tabular}{|l|c|c|c|c|}
\hline Item 2 & Frequency & Percent (\%) & Valid Percent (\%) & Cumulative Percent (\%) \\
\hline Disagree & 3 & 3.846 & 3.846 & 3.846 \\
\hline Not sure & 8 & 10.256 & 10.256 & 14.103 \\
\hline Agree & 67 & 85.897 & 85.897 & 100.000 \\
\hline Missing & 0 & 0.000 & & \\
\hline Total & 78 & 100.000 & & \\
\hline
\end{tabular}

Many of the respondents $(n=67,85.9 \%)$ agreed that the tasks performed by the Shari'ah Committee of my institution were significant in the broader scheme of things. Only 3 respondents $(3.8 \%)$ disagreed with this statement while 8 $(10.3 \%)$ were not sure. The results suggested that the Shari'ah Committee tasks were regarded as significant in the institution.

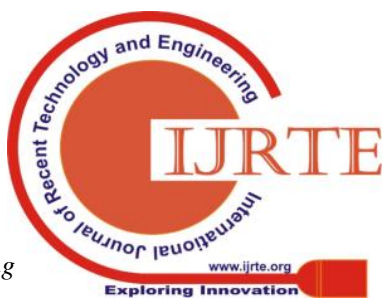


Table 4.20: Distribution for Shari'ah Committee

The Shari'ah Committee of my institution is given considerable opportunity for independence in delivering their tasks.

\begin{tabular}{|l|c|c|c|c|}
\hline Item 3 & Frequency & Percent (\%) & Valid Percent (\%) & Cumulative Percent (\%) \\
\hline Not sure & 5 & 6.410 & 6.410 & 6.410 \\
\hline Agree & 73 & 93.590 & 93.590 & 100.000 \\
\hline Missing & 0 & 0.000 & & \\
\hline Total & 78 & 100.000 & & \\
\hline
\end{tabular}

Interestingly, not a single respondent disagreed that the Shari'ah Committee of their institution were givenconsiderable opportunity for independence in delivering their tasks with $73(93.6 \%)$ respondents agreeing with this. Only $5(6.4 \%)$ were not sure of whether opportunity for independencewere given to the Shari'ah Committee. The results suggested that the Shari'ah Committee was givenhigh level of opportunity for independence in performing their tasks.

Table 4.21: Distribution for Shari'ah Compliance Functions The responsibilities of the Shari'ah Compliance functions as required by the Shari'ah Governance Framework are clearly set out in writing.

\begin{tabular}{|l|c|c|c|c|}
\hline Item 1 & Frequency & Percent (\%) & Valid Percent (\%) & Cumulative Percent (\%) \\
\hline Disagree & 1 & 1.282 & 1.282 & 1.282 \\
\hline Not sure & 8 & 10.256 & 10.256 & 11.538 \\
\hline Agree & 69 & 88.462 & 88.462 & 100.000 \\
\hline Missing & 0 & 0.000 & & \\
\hline Total & 78 & 100.000 & & \\
\hline
\end{tabular}

Only one respondent disagreed that the responsibilities of the Shari'ah Compliance functions as required by the Shari'ah Governance Framework were clearly set out in writing while $8(10.3 \%)$ were not sure with this statement. Majority $(n=69$, $88.5 \%$ ) agreed in which this suggested that responsibilities were clearly written.

Table 4.22: Written document on responsibilities of Shari'ah Compliance Functions in relation to Shari'ah Governance Framework

\begin{tabular}{|l|c|}
\hline \multicolumn{1}{|c|}{ Type of Documents } & Frequency \\
\hline Internal Shari'ah Governance Framework Policy or Manual & 18 \\
\hline Shari'ah Compliance Manual or Policy or Standard Operation Procedure or Charter & 9 \\
\hline Internal policies and procedures for Shar'ah Compliance functions & 7 \\
\hline Shari'ah Review Manual and Shar''ah Research Manual & 2 \\
\hline Group Compliance Policy & 1 \\
\hline Internal Policy and Terms of Reference of Shari'ah Compliance Functions & 1 \\
\hline Shari'ah Compliance Review Procedure & 1 \\
\hline Standard Operation Procedure of Shari'ah Division & 1 \\
\hline Job Description of Shar'ah Compliance functions & 1 \\
\hline Total & 41 of 78 \\
& respondents \\
\hline
\end{tabular}

18 respondents affirmed that their internal Shari'ah governance framework policy stated the responsibilities of Shari'ah Compliance functions such as Shari'ah Review, Shari'ah Research, Shari'ah Audit as well as Shari'ah Risk Management. Meanwhile, some other respondents claimed that this was stated in different internal policies such as Shari'ah Review Manual, Shari'ah Research Manual, Shari'ah Compliance Review Procedure, its standard operating procedure as well as the job description of respective function within an IFI. It can be seen that there were different documents stating the responsibilities of Shari'ah compliance functions represented by these respondents.

Table 4.23Distribution for Shari'ah Compliance Functions In my institution, the Shari'ah Compliance functions are given the chance to complete the tasks assigned from beginning to end.

\begin{tabular}{|l|c|c|c|c|}
\hline Item 2 & Frequency & Percent (\%) & Valid Percent (\%) & Cumulative Percent (\%) \\
\hline Disagree & 1 & 1.282 & 1.282 & 1.282 \\
\hline Not sure & 3 & 3.846 & 3.846 & 5.128 \\
\hline Agree & 74 & 94.872 & 94.872 & 100.000 \\
\hline Missing & 0 & 0.000 & & \\
\hline Total & 78 & 100.000 & & \\
\hline
\end{tabular}

Majority of the respondents $(n=74,95.0 \%)$ agreed that the Shari'ah Compliance functions were given the chance to complete the tasks assigned from beginning to end. While 3 $(3.8 \%)$ of respondents were not sure, only $1(1.3 \%)$ respondent disagreed with this statement. The results indicated that the Shari'ah Compliance functions were givenconsiderable chance to complete the assigned tasks in the IFI.

Table 4.25: Distribution for Shari'ah Compliance Functions In my institution, the tasks assigned to Shari'ah Compliance function itself provides feedback on their performance.

\begin{tabular}{|l|c|c|c|c|}
\hline Item 3 & Frequency & Percent (\%) & Valid Percent (\%) & Cumulative Percent (\%) \\
\hline Disagree & 2 & 2.564 & 2.564 & 2.564 \\
\hline Not sure & 5 & 6.410 & 6.410 & 8.974 \\
\hline Agree & 71 & 91.026 & 91.026 & 100.000 \\
\hline Missing & 0 & 0.000 & & \\
\hline Total & 78 & 100.000 & & \\
\hline
\end{tabular}

A large number of respondents $(n=71,91.0 \%)$ agreed that the tasks assigned to the Shari'ah Compliance function itself provide feedback on their performance. Only $2(2.6 \%)$ disagreed with $5(6.4 \%)$ not sure. The results suggested that tasks completed by the Shari'ah Compliance function were utilized as feedback for their performance. Table 4.29 below illustrated the result for Section 4 of the survey.

Table 4.26Result of the Survey for Section 4.3 in Frequency and Percentage Output

\begin{tabular}{|c|c|c|c|}
\hline No. & Item & \multicolumn{2}{|c|}{ Response / Frequency / Percentage } \\
\hline \multicolumn{4}{|c|}{ BOARD OF DIRECTORS } \\
\hline 1 & $\begin{array}{l}\text { In my institution, responsibilities } \\
\text { of the Board of Directors in } \\
\text { relation to Shar'ah Govemance } \\
\text { Framework is clearly set out in } \\
\text { writing. }\end{array}$ & \begin{tabular}{|l} 
1. Agree \\
2. Disagree \\
3. Not Sure \\
Type of written o \\
1) Intemal \\
Policy or \\
2) Terms of \\
3) Board Cl \\
4) Fit and P \\
5) Intemal \\
6) Meeting \\
7) Shar'ah \\
8) Terms an
\end{tabular} & $\begin{array}{l}52 / 78(66.7 \%) \\
3 / 78(3.8 \%) \\
22 / 78(28.2 \%) \\
\text { vemance Framework } \\
\text { nents } \\
\text { procedures } \\
\text { Manual or Policy } \\
\text { Is }\end{array}$ \\
\hline 2 & $\begin{array}{l}\text { In my institution, the tasks } \\
\text { performed by the Board of } \\
\text { Directors have a significant } \\
\text { impact on people outside the } \\
\text { institution. }\end{array}$ & $\begin{array}{ll}\text { 1. Agree } \\
\text { 2. Disagree } \\
\text { 3. Not Sure }\end{array}$ & $\begin{array}{l}46 / 78(59.0 \%) \\
8 / 78(10.3 \%) \\
24 / 78(30.8 \%)\end{array}$ \\
\hline 3 & $\begin{array}{l}\text { In my institution, the Board of } \\
\text { Directors are provided with } \\
\text { significant autonomy in } \\
\text { making decision. }\end{array}$ & $\begin{array}{ll}\text { 1. Agree } \\
\text { 2. Disagree } \\
\text { 3. Not Sure }\end{array}$ & $\begin{array}{l}59 / 78(75.6 \%) \\
7 / 78(9.0 \%) \\
12(15.4 \%)\end{array}$ \\
\hline
\end{tabular}

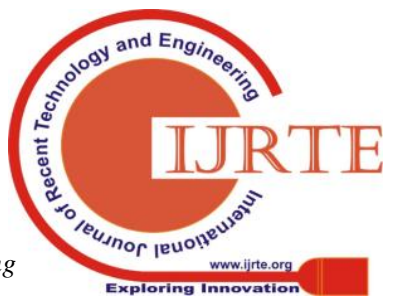




\begin{tabular}{|c|c|c|}
\hline \multicolumn{3}{|c|}{ MANAGEMENT } \\
\hline 1 & $\begin{array}{l}\text { Inmy institution, the } \\
\text { responsibilities of the } \\
\text { Management on Shar'ah } \\
\text { Govemance matters are clearly } \\
\text { set out in writing. }\end{array}$ & 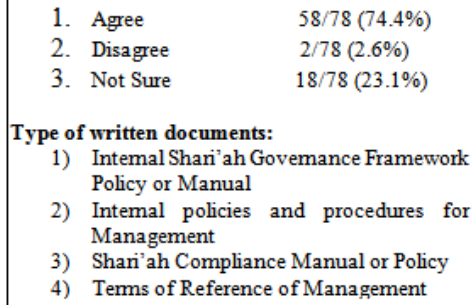 \\
\hline 2 & $\begin{array}{l}\text { In my institution, the roles } \\
\text { played by the Management } \\
\text { involve a great deal of skill } \\
\text { variety. }\end{array}$ & $\begin{array}{l}64 / 78(82.1 \%) \\
7 / 78(9.0 \%) \\
7 / 78(9.0 \%)\end{array}$ \\
\hline 3 & $\begin{array}{l}\text { In my institution, the } \\
\text { Management is allowed to } \\
\text { determine the procedure to be } \\
\text { used in carrying out their } \\
\text { duties. }\end{array}$ & $\begin{array}{l}65 / 78(83.3 \%) \\
1 / 78(1.3 \%) \\
12(15.4 \%)\end{array}$ \\
\hline \multicolumn{3}{|c|}{ SHARIAH COMMITTEE } \\
\hline 1 & $\begin{array}{l}\text { The responsibilities of the } \\
\text { Shar'ah Committee of my } \\
\text { institution are clearly set out in } \\
\text { writing. }\end{array}$ & $\begin{array}{l}\text { 1. Agree } 71 / 78(91.0 \%) \\
\text { 2. Disagree } 1 / 78(1.3 \%) \\
\text { 3. Not Sure } 6 / 78(7.7 \%) \\
\text { Type of written documents: } \\
\text { 1) Terms of Reference of Shar'ah } \\
\text { Committee } \\
\text { 2) Intemal Shar'ah Govemance Framework } \\
\text { Policy or Manual } \\
\text { 3) Intemal Shar'ah Govemance Framework } \\
\text { Policy and Terms of Reference of } \\
\text { Shar'ah } \\
\text { Committee } \\
\text { 4) Tems and Conditions if appointment of } \\
\text { Shar'ah Committee } \\
\text { 5) Intemal policies and procedures for } \\
\text { Shar'ah } \\
\text { 6) Sharn'ah Compliance Manual or Policy } \\
\text { 7) Fit and proper documents for Shar'ah } \\
\text { Committee }\end{array}$ \\
\hline 2 & $\begin{array}{l}\text { The tasks performed by the } \\
\text { Shar'ah Committee of my } \\
\text { institution are very significant } \\
\text { in the broa der scheme of things. }\end{array}$ & $\begin{array}{l}67 / 78(85.9 \%) \\
3 / 78(3.8 \%) \\
8 / 78(10.3 \%)\end{array}$ \\
\hline 3 & $\begin{array}{l}\text { The Shar'ah Committee of my } \\
\text { institution are given } \\
\text { considerable opportunity for } \\
\text { independence in delivering } \\
\text { their tasks. }\end{array}$ & $\begin{array}{l}73 / 78(93.6 \%) \\
0 / 78(0 \%) \\
5 / 78(6.4 \%)\end{array}$ \\
\hline \multicolumn{3}{|c|}{ SHARIAH COMPLIANCE FUNCTIONS } \\
\hline 1 & $\begin{array}{l}\text { The responsibilities of the } \\
\text { Shar'ah Compliance functions } \\
\text { as required by the Shar'ah } \\
\text { Govemance Framework are } \\
\text { clearly set out in writing. }\end{array}$ & \begin{tabular}{|l} 
1. Agree $69 / 78(88.5 \%)$ \\
2. Disagree $1 / 78(1.3 \%)$ \\
3. Not Sure $\quad 8 / 78(10.3 \%)$ \\
Type of written documents: \\
1) Intemal Shar'ah Govemance Framework \\
Policy or Manual \\
2) Shar'ah Compliance Manual or Policy \\
or Standard Operation Procedure or \\
Charter \\
3) Interal policies and procedures for \\
Shar'ah Compliance functions \\
4) Shar'ah Review Manual and Shar'ah \\
Research Manual \\
5) Group Compliance Policy \\
6) Internal Policy and Terms of Reference \\
of Shar'ah Compliance Functions \\
7) Shar'ah Compliance Review Procedure \\
8) Standard Operation Procedure of \\
Shan'ah Division \\
9) Job Description of Shari'ah Compliance \\
functions
\end{tabular} \\
\hline 2 & $\begin{array}{l}\text { In my institution, the Shari'ah } \\
\text { Compliance functions are given } \\
\text { the chance to complete the tasks } \\
\text { assigned from beginning to end. }\end{array}$ & $\begin{array}{l}74 / 78(95.0 \%) \\
1 / 78(1.3 \%) \\
3 / 78(3.8 \%)\end{array}$ \\
\hline 3 & $\begin{array}{l}\text { In my institution, the tasks } \\
\text { assigned to Shari'ah } \\
\text { Compliance function itself } \\
\text { provides feedback on their } \\
\text { performance. }\end{array}$ & $\begin{array}{l}71 / 78(91.0 \%) \\
2 / 78(2.6 \%) \\
5 / 78(6.4 \%)\end{array}$ \\
\hline
\end{tabular}

In addition to these statistical data, there was one feedback received from one of Retakaful Operator's manager who was not able to provide his feedback on the survey questionnaires. Based on his email sent to the researcher on 30 July 2018, this Retakaful operator received exemptions from the BNM on some major aspects of the SGF. Hence, it was not relevant for him to revert and provide the feedback since these aspects were not applicable for the institution. Based on this feedback, it was concluded that not all IFIs implemented the framework in the same way and the BNM granted exemptions where necessary.

The results showed that majority of the respondents $(50 \%$ and above of total respondents) agreed with each item stated by the researcher in Section 4.3 of the survey questionnaires. As for Board of Directors, 59.0\% of respondents agreed that their tasks provided a significant impact toward people outside the institution and $75.6 \%$ respondents perceived that they were given significant autonomy in making a decision. Meanwhile, $82.1 \%$ respondents believed that the roles of Management involved a great deal of skill variety and $83.3 \%$ respondents agreed that they were also allowed to determine which procedures to be used to complete their assigned tasks. Additionally, the roles played by the Shari'ah Committee were significant in a broader scheme of things (85.9\%) and were given considerable opportunity for independence to carry out their tasks (93.6\%). 95.0\% respondents agreed that Shari'ah Compliance functions were trusted with considerable chance to complete their tasks and $91.0 \%$ believed that their tasks itself provided feedback on their own performance. These agreements also indicated that respondents' IFIs effectively used and utilized its HRM's practice in terms of Job design and description on its key Shari'ah governance organs or functions. It also showed that the key governance organs' responsibilities were clearly written as expected in different types of document as practiced by different IFIs. Clear job design and description of key governance organs are essential to promote good governance practices in IFIs. When all Shari'ah governance key functions understand their roles and duties, the implementation of the framework becomes successful and effective.

\section{IMPLICATIONS, RECOMMENDATIONS AND CONCLUSION}

The implications were provided based on the findings stated earlier. It can be seen that the general understanding of the participating respondents on the SGF implementation and its incorporation in HRM practice was fairly good and satisfactory. The data collected and analyzed were represented from two main departments or divisions under this study, namely Shari'ah Division and HR Division. Hence, regardless of respondents' background and specialization area, the respondents were, directly and indirectly, involved in SGF implementation as required by the BNM to its licensed IFIs. Nevertheless, there was a lack of concern shown by the respondents or inadequate information sourced to some of the respondents particularly on internal HRM practices that incorporate Shari'ah governance elements. In addition to this, the general understanding on SGF as indicated earlier was relatively good and was slightly average when it came to some specific requirements stated in the framework.

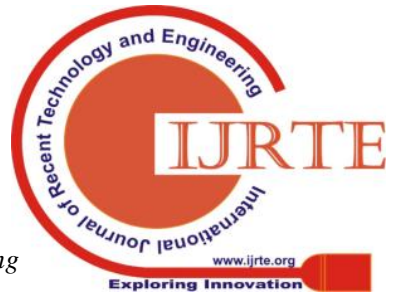


Nonetheless, there will always be a platform to improve the current practice of IFI with regard to this matter. The following are some recommendations based on the findings and results discussed earlier:

To upgrade and enhance the understanding, awareness and knowledge of SGF implementation among IFIs' employees, specifically in relation to the specific requirements of SGF. SGF is not only limited to Shari'ah matters since its primary objective is to strengthen the functions and roles of key governance as specified in the framework. Nonetheless, effective implementation of SGF should not be limited to these organs' responsibilities but also involves the supporting functions which also play an integral role in this implementation. Therefore, in-depth knowledge and an understanding of SGF are equally important to all level of employees. For this purpose, they would need to be equipped with appropriate and continuous learning and knowledge-based environment which not only emphasizes on Shari'ah knowledge but also Shari'ah governance and regulatory related understanding and knowledge. Useful knowledge and in-depth understanding towards Shari'ah governance elements would inculcate good Shari'ah governance practices within an IFI.

To provide clear information and updates to all employees on HRM practices that embed SGF elements and requirements. This information should be available online and within employees' reach and means as it is undeniably good and beneficial for them to know what are the initiatives that have been arranged and done to ensure end-to-end Shari'ah governance practices within an IFI.

To strengthen and improve the incorporation of internal Shari'ah governance and HRM practices within an IFI for better and effective implementation of SGF. This is important to note since the new enhanced SGF will come into effect for the industry soon, and it will definitely expect better Shari'ah governance practices in these IFIs.

\section{REFERENCES}

1. Amin, H., Rahman, A. R. A., Sondoh Jr, S. L., \& Hwa, A. M. C. (2011). Determinants of customers' intention to use Islamic personal financing: The case of Malaysian Islamic banks. Journal of Islamic Accounting and Business Research, 2(1), 2242.

2. Bank Negara Malaysia. (2010). Shari ah Governance Framework for Islamic Financial Institutions. Kuala Lumpur: Bank Negara Malaysia

3. Bhagat, C. and Kehoe, C. (2014). High-performing boards: what's on their agenda? McKinsey Quarterly. Retrieved from https://www.mckinsey.com/business-functions/strategy-and-corporate-fi nance/our-insights/high-performing-boards-whats-on-their-agenda

4. Ernst and Young LLP. (2014). Adding value: A guide for boards and HR committees in addressing human capital risks and opportunities. UK: Ernst and Young LLP.

5. Harun, H. and Abdullah. N.I. (2017). Enhancing Shari'ah governance framework for Malaysian IFIs through effective management strategies. International Journal of Public Finance 2(1), 63-80.

6. Hasan, Z. (2009). Corporate governance: Western and Islamic perspectives. International Review of Business Research Papers 5(1), 277-293.

7. Htay, N., Nu, S., \& Salman, S. A. (2014). Introducing Takaful in India: An Exploratory Study on Acceptability, Possibility and Takaful Model. Asian Social Science, 10(1), 117.

8. Htay, S. N. N., \& Salman, S. A. (2013). Viability of Islamic Insurance (Takaful) in India: SWOT Analysis Approach. Review of European Studies, 5(4). 145.

9. Huselid, M., Jackson, S., Schuler, R. (1997). Technical and strategic human resource management effectiveness as determinants of firm performance. The Academy of Management Journal 40(1), 171-188.

10. ISRA. (2012). Islamic Financial System: Principles and Operations. Kuala Lumpur: Pearson Custom Publishing.
11. Knightsbridge Human Capital Solution, Clarkson Centre for Board Effectiveness, Institute of Corporate Directors. (2011). Beyond the CEO. Research Report September 2011. Canada: Knightsbridge.

12. Parker, M. (2017). BNM's Syariah governance. Retrieved from https://www.nst.com.my/opinion/columnists/2017/12/319043/bnms-sya riah-governance

13. Rahman, A. (2008). Shari ah audit for Islamic financial services: the needs and challenges. ISRA Islamic Finance Seminar. Kuala Lumpur: ISRA.

14. Redzuan, H., Rahman, Z. A., \& Aidid, S. S. (2009). Economic determinants of family takaful consumption: Evidence from Malaysia. International Review of Business Research Papers, 5(5), 193-211.

15. Shafii, Z., Salleh, S., M. Hanefah, M., Jusoff, K. (2013). Human capital development in Shari ah audit. Middle-East Journal of Scientific Research 13 (Research in Contemporary Islamic Finance and Wealth Management. 28-34.

16. Yussof, S.A. (2013). The Islamic Financial Services Act 2013: Malaysia's model framework for Shariah-compliance and stability. Islamic and Civilisation Renewal 4(3), 391-406. 